ARTIGOS "TiRADUZIDOS/

TrRanslated A RTICLes 


\title{
EXPLORANDO A DIFERENÇA CULTURAL ATRAVÉS DA TRADUÇÃO DE LITERATURA INFANTIL ${ }^{1}$
}

\author{
Eva-Maria Metcalf* \\ University of Mississippi \\ Tradução de: Newton de Castro Pontes** \\ Universidade Regional do Cariri
}

\begin{abstract}
Resumo: Este artigo, de natureza descritiva, apresenta um projeto alunoprofessor em que os participantes traduziram um conto infantil do alemão para o inglês a fim de explorar o caráter cultural da linguagem e a natureza hermenêutica da tradução. Ao refletir sobre os problemas que envolvem a tradução de literatura infantil e ao simular a situação de um tradutor profissional, os participantes do projeto aprofundaram sua visão sobre os mecanismos da linguagem e as complexidades associadas ao trabalho de tradução.
\end{abstract}

Palavras-chave: Diferenças culturais. Tradução Alemão-Inglês. Conto. Projeto aluno-professor.

\footnotetext{
* Eva-Maria Metcalf, foi professora de Língua e Literatura Alemã e diretora de Estudos Germânicos na University of Mississippi, onde desenvolveu pesquisas sobre aquisição da linguagem e sobre literaturas infantis germânicas e do norte europeu. Aposentou-se em 2009. Publicou vários artigos acerca desses temas, incluindo a obra Astrid Lindgren, sobre a escritora sueca de literatura infantil. E-mail: emetcalf@olemiss.edu

** Newton de Castro Pontes, tradutor deste artigo, é professor de Teoria da Literatura na Universidade Regional do Cariri e possui doutorado em Teoria da Literatura pela Universidade Federal de Pernambuco. Cariri, Pernambuco, Brasil. E-mail: newtondecastrop@hotmail.com
} 


\title{
EXPLORING CULTURAL DIFFERENCE THROUGH TRANSLATING CHILDREN'S LITERATURE
}

\begin{abstract}
This article is descriptive in nature, presenting a studentfaculty project in which participants translated a short children's story from German into English in order to explore the cultural embeddedness of language and the hermeneutic nature of translation. By reflecting on issues surrounding the translation of children's literature and by imitating the situation of a professional translator, project participants gained insight into the workings of language and the complexities associated with translation.
\end{abstract}

Keywords: Cultural differences. German to English translation. Short story. Student-faculty project.

\section{O Projeto}

Há alguns anos atrás, recebi fundos ligados a técnicas de ensino inovadoras com o objetivo de desenvolver um projeto de pesquisa independente, de caráter aluno-professor, voltado para graduandos do terceiro ano (nível intermediário) do curso de Alemão em uma universidade americana. O projeto consistia de quatro estudantes americanos e eu, e nos reuníamos uma vez por semana para traduzir alguma história infantil simples do alemão para o inglês, língua nativa dos estudantes. A ideia era produzir uma tradução de qualidade profissional, publicável, de um texto sem tradução disponível, simulando assim o trabalho de um tradutor profissional.

Obviamente, nosso tipo de tradução era muito distante do tradicionalmente praticado em aulas de língua estrangeira. Nosso foco não estava nos mecanismos linguísticos, isto é, não buscávamos traduzir frases a fim de entender seu sentido ou reconhecer construções gramaticais em particular. Compreender a forma e o conteúdo das histórias infantis alemãs era, de fato, um trabalho simples, graças à simplicidade lexical e gramatical dos textos escolhidos. Compreender o texto era apenas a pré-condição do trabalho a seguir, que consistia em como melhor captar o sentido e sabor 
do texto e em estabelecer o contexto cultural no qual ele tinha sido originalmente situado, replicando isso de alguma maneira na língua alvo. A experiência do aprendizado se voltou para um entendimento mais profundo dos modos como a linguagem conceptualiza o mundo e as dificuldades que encontramos em reconceptualizá-lo quando o transportamos para uma língua e cultura diferentes.

Por causa da limitada habilidade linguística dos estudantes que deveriam assumir o papel de tradutores profissionais com um certo nível de conforto, os textos a serem traduzidos precisavam ser muito simples linguisticamente. A literatura infantil se tornou uma escolha natural por sua relativa simplicidade linguística. Seu vocabulário limitado, sua sintaxe relativamente simples, seu uso liberal de ilustrações e o fato de que o conteúdo normalmente permanece próximo das experiências quotidianas das crianças fizeram dela mais acessível aos alunos do que a ficção e a nãoficção escritas para adultos. Porém, há outros benefícios na escolha da literatura infantil. O enredo envolvente, a tendência de representar o pensamento abstrato ou analítico através de imagens concretas e a tendência de se expressar concretamente no lugar de usar noções inferidas auxiliam o leitor desacostumado àquela cultura. Ademais, a missão da literatura infantil, que visa socializar jovens leitores com os padrões de pensamento, códigos, normas, valores e hábitos de uma cultura específica tornaram-na ideal para um projeto intercultural como o nosso. O papel que assumimos de tradutores nos forçou a detectar e expor as restrições culturais impostas à literatura infantil de ambas as culturas linguísticas e, por fim, ampliou nossa consciência do fato de que tendíamos a impor um segundo filtro cultural na história que traduziríamos.

Os horizontes cognitivos e experienciais do leitor real e - consequentemente - implícito na literatura infantil são, em geral, mais limítrofes que os de um leitor adulto, especialmente de um leitor adulto erudito. Quanto a isso, um estudante que se encontra no processo de aprender uma língua estrangeira e sua cultura possui muito em comum com o leitor infantil. Mas a analogia não é de nenhuma forma perfeita; existe uma assimetria entre a mentalidade 
sobretudo adulta do estudante e a assumida ausência dessa mentalidade no leitor implícito. Além disso, o estudante estrangeiro carece do conhecimento íntimo do mundo físico, social e moral representado por e presente na língua estrangeira. Essa assimetria pode ser superada pelo processo de análise, interpretação e recodificação dos conteúdos, imagens e ideias da história. A própria literatura infantil já se modificou, tornando a leitura de histórias infantis contemporâneas uma proposição mais atraente para estudantes. Mais do que nunca, livros infantis se dirigem a uma audiência dupla de crianças e adultos, o que, por outro lado, traz um desafio duplo para o tradutor, o qual agora deve também se dirigir a ambas as audiências na língua alvo.

Os estudantes que não possuem a visão bicultural requerida a um bom tradutor podem estar cegos a alguns dos desafios que 0 texto estrangeiro representa. No entanto, o esforço deliberado que acompanha a atividade de tradução, especificamente o de entender a história dentro de seu próprio contexto a fim de realizá-la de modo comparável no novo contexto da língua alvo, neutraliza um pouco dessa cegueira. Meu papel como líder do projeto e informante dos sistemas de valores e realidades sociais da Alemanha do tempo em que a história foi escrita restaurou um pouco da visão bicultural necessária. Ao serem forçados a comparar, tomar decisões e resolver as disparidades existentes, os estudantes participantes se tornaram leitores críticos. Junto com a compreensão das diferenças culturais que eles puderam captar do texto, veio também uma percepção crescente de seus próprios pontos de vista pessoais e culturais.

Além do meu desejo de sensibilizar estudantes americanos (os quais normalmente têm pouca ou nenhuma experiência com culturas estrangeiras) ao papel da linguagem no processo de construção do sentido, o projeto também foi construído de modo a tornar a aprendizagem mais imediatamente rica e envolvente. O dever de traduzir um texto "autêntico" para uma possível publicação deu aos estudantes um incentivo para se sobressaírem, e o processo manual de tradução lhes proveu um meio para um aprendizado experiencial. 


\section{O Processo}

Começamos o projeto com algumas deliberações preparatórias, tais como tentar definir o lugar da criança e da literatura infantil dentro do contexto social e nos perguntar o que seria necessário para uma tradução de qualidade profissional de um conto infantil. Discutimos questões plenas de valores, como: O que é a infância? O que é um bom livro infantil? O que é uma boa tradução? Qual é a função do tradutor? Qual é o público pretendido e implícito de nossa tradução? O que pode afetar as escolhas do tradutor, do revisor e da editora? Seguiu-se então um período de leitura fortuita das e sobre as literaturas infantis alemã e americana, e de teorias de tradução (de acordo com os recursos na universidade e bibliotecas locais: incluímos Eugene Nida, Peter Newmark, Zohar Shavit, Göte Klingberg) que nos ajudaram a estabelecer uma hipótese funcional de tradução.

A missão do projeto, aprofundar a compreensão intercultural, foi modificada pelo nosso viés de tradução. Fomos inicialmente inspirados pela afirmação de Mildred L. Batchelder em 1972, reimpressa em uma publicação local de literatura infantil chamada The Children's Book Bag [A Mochila de Livros das Crianças]: “As crianças de um país que vêm a conhecer os livros e histórias de muitos países deram um passo rumo ao entendimento internacional" (THE CHILDREN'S, 1990, p. 1). Entretanto, uma vez que confrontamos traduções reais e trabalhos de tradução, logo percebemos que aquela afirmação servia como bom grito de guerra para ativistas como Mildred Batchelder ou Jella Lepman, mas deveria ser lida com muita cautela. A afirmação não considera os efeitos do inevitável processo de triagem que um texto infantil sofre ao passar pelas mãos de tradutores, editores, do mercado editorial, mediadores e do leitor, o que pode deslocar ou mesmo anular qualquer influência intercultural.

Tornamo-nos conscientes dos efeitos que a imposição de vários processos de triagem poderia ter sobre um texto ao examinar excertos das edições americanas e britânicas do romance de Chris- 
tine Nöstlinger, Konrad oder das Kind aus der Konservenbüchse (1975) [publicado em inglês como Conrad: The factory-made boy e em português como Konrad - $O$ menino da lata], ambas baseadas na tradução de Anthea Bell. As diferenças eram gritantes. Os primeiros capítulos da premiada edição americana de Batchelder foram seriamente encurtados (o primeiro capítulo foi reduzido a um terço do original) e, em geral, simplificados para enfatizar as sequências de ação na história. A mensagem antiautoritária e feminista de Nöstlinger foi atenuada um pouco na versão britânica e bastante na americana. As ilustrações alemãs que foram mantidas na edição britânica haviam sido substituídas por ilustrações americanas feitas domesticamente, situando as crianças de Viena em um cenário genericamente americano.

O fundo teórico e os exemplos ilustrativos nos prepararam para abordar nossa própria tradução com maior circunspecção e com determinação para ir contra a tendência de americanizar que parecia prevalente nas traduções americanas dos anos 1970 e 1980 . O fato de que apenas $1.2 \%$ de todos os livros produzidos nos Estados Unidos em 1995 eram traduções (TOMLINSON, 1998, p. 14), comparados a cerca de $80 \%$ na Finlândia durante a mesma década, como observou Riita Oittinen (2000, p. XIII), produz um público leitor nos Estados Unidos que tem pouco conhecimento de e pouca tolerância para o estrangeirismo. Muitos dos livros que são traduzidos nos Estados Unidos passaram por uma seleção rígida, baseada em projeções de sua potencial adoção por consumidores e de seu sucesso financeiro. Isso resulta em uma seleção "natural" de livros que são adaptáveis à cultura alvo.

Um conto de cinco páginas de Susanne Kilian, "Jürgen Körner, 8 Jahre, 2. Schuljahr", publicado em 1971 na antologia de literatura infantil Geh, spiel mit dem Riesen, serviu como texto principal para o projeto. Essa história curta e simples provou-se satisfatória de um ponto de vista sociocultural. Escrita em uma prosa minimalista, bem concisa, a narrativa em primeira pessoa dá aos leitores vislumbres da vida de um menino de oito anos em estado de negligência. Conta-nos sobre sua vida quotidiana em casa e na escola, 
presa em uma teia de abusos recebidos e cometidos. A maioria das frases são orações principais, as mais longas combinações sintáticas consistem de uma combinação simples entre uma oração principal e uma subordinada, e o vocabulário consiste naquele de uma criança de oito anos não muito articulada (na terminologia da aquisição de uma segunda língua, a linguagem se encontra entre o intermediário-baixo e o intermediário-médio).

Uma vez que lemos e discutimos a história para ter uma impressão e comparar entre si nossas respostas a ela, discutimos o conceito de infância subjacente à história, sua posição ideológica e mensagem. Impressões sobre o conceito de infância do autor variaram assim como as impressões sobre as atitudes do tradutor em relação ao público implícito. Qual de nossas preferências pessoais deveria prevalecer? Estávamos igualmente divididos sobre o que fazer com a ideologia esquerdista em um texto que tem pouca ressonância na cultura alvo. Deveríamos mantê-la? A adaptação é uma necessidade, uma autopreservação ou autocensura?

Repletos de questões não resolvidas, nós abordamos a tarefa de traduzir sentença por sentença. Cada um de nós traduziu uma passagem do texto designada individualmente e, durante os encontros, comparamos e discutimos nossos resultados. Durante as sessões de discussão, os estudantes tiveram ampla oportunidade para expor suas ideias novamente. Questões estilísticas, assim como semânticas e ideológicas logo estavam no centro de (por vezes) calorosos debates sobre as versões na língua alvo. Apesar da simplicidade linguística e das limitações de conteúdo, a história continha uma incrível quantidade de informações culturalmente específicas. Encontrar o registro, o tom e o ritmo corretos não era tão simples quanto parecia a princípio. Talvez o maior desafio foi posto por palavras e conceitos especificamente culturais. Como traduzir nomes pessoais e geográficos, itens alimentícios, jogos e tradições que não existem na língua alvo? Como converter palavras como "pausenbrot", a qual não é o mesmo que o "lunch pail" do inglês, já que o almoço escolar não existe na Alemanha? "Schulranzen" era igualmente intraduzível como mochila. Esta transmite a mensagem de que as 
crianças alemãs carregam as bolsas escolares nas costas, mas não transmite a esperada limpeza, organização e supervisão em casa dos deveres escolares, sobre cujos aspectos a história se sustenta. Nós mantivemos "mochila" e tentamos enfatizar de outras formas a organização com que os papéis e lápis eram guardados. Como explicar a importância da tradição pré-natalina do "Adventskranz" alemão para leitores americanos, uma vez que a compreensão integral da história depende disso? Um esclarecimento em nota de rodapé parecia desajeitado, mas acredito que optamos por ele. Em geral, nossos pontos de vista conflitantes foram resolvidos com transigência em relação à tradução e resultou em um texto mais ou menos consistente. No entanto, emergiu com clareza a qualidade subjetiva e culturalmente determinada da tradução, que era afinal a experiência de aprendizagem buscada.

A maioria de nossas discussões nos levaram de volta às questões fundamentais que os tradutores têm posto há séculos. Como alguém traduz um conjunto diferente de normas e valores, um corpo não familiar de referências e conotações, além de expressões e conceitos culturalmente específicos enquanto os torna confortáveis ao leitor sem perder a significância cultural deles? Essas discussões que atingem o seio da tradução também nos levaram bem longe através da história, política e vida quotidiana das duas áreas culturais.

\section{O Resultado}

No fim, não publicamos nossa tradução, embora fosse esse um dos propósitos do projeto. Mas era, afinal, não o produto (ainda que fosse um importante ímpeto para o projeto), mas o processo o que contava, e foi o processo que gerou a experiência de aprendizagem. Pôr a tradução na internet e incentivar outros a melhorá-la teria sido uma ótima ideia, uma que eu gostaria de perseguir no futuro. Ainda assim, o projeto deu origem a artigos de pesquisa, os quais foram apresentados pelos estudantes em uma conferência nacional para graduandos pesquisadores no semestre seguinte. 
O foco nesses artigos foi uma tentativa de achar uma resposta para as questões que debatêramos e decidíramos em nossa tradução. Em grande medida, os estudantes optaram por ir contra uma adaptação para a cultura alvo que facilitasse a leitura do texto e preferiram manter intacta muito da alteridade da cultura estrangeira em sua tradução. Seus esforços para moldar suas traduções, de modo que as crianças americanas pudessem ter uma visão mais ampla ao experimentar a diferença e assim obter um mínimo de conhecimento intercultural, foi claramente uma decisão política da parte deles em um tempo em que o multiculturalismo e a globalização emergente se tornaram termos familiares. Isso destacou o fato de que a tradução estará sempre sujeita às pressões políticas, morais, sociais, econômicas, culturais, religiosas, ideológicas, psicológicas e outras que devem ser reconhecidas. Por causa da missão de educar, percebida na literatura infantil, os jovens estudantes sentiram-se inclinados a se esgueirar para o papel de educadores tanto quanto o de tradutores, papel que é familiar a muitos tradutores, revisores e editores de literatura infantil. Essa mesma atitude tem - pelo menos nos Estados Unidos - produzido traduções excessivamente aculturadas de histórias infantis, as quais são muito menos repreensíveis e mais padronizadas que os textos originais.

Alguns resultados do projeto eram esperados, enquanto outros se adicionaram como bônus. Nem é preciso ressaltar como o projeto melhorou a habilidade linguística dos estudantes. Trabalhar de perto e criativamente com a linguagem melhorou seus domínios de gramática e de vocabulário, também sua sensibilidade ao registro e estilo. Tornar o papel do tradutor algo visível também aprofundou seu amor pela linguagem e seu respeito pelo ofício do tradutor. Ao fim do projeto, a apreciação dos estudantes pela complexidade da tradução tinha crescido exponencialmente. O trabalho em equipe de uma tradução conjunta converteu a competitividade em cooperação. Os estudantes se tornaram especialistas ao embarcar em uma tradução profissional do alemão simples para o inglês, e eles podiam se orgulhar (e, de fato, se orgulharam) do trabalho feito. Afinal, há uma maneira melhor de aprender que não seja aprender pela experiência? 


\section{Nota}

1. O artigo, originalmente intitulado "Exploring Cultural Difference Through Translating Children's Literature", foi publicado por Meta: journal des traducteurs / Meta: Translators' Journal, Montréal, vol. 48, n. 1-2, 2003, p. 322-327.

\section{Referências}

KILIAN, S. "Jürgen Körner, 8 Jahre, 2. Schuljahr". In: GELBERG, HansJoachim (Org.). Geh, spiel mit dem Riesen. Weinheim und Basel: Beltz \& Gelberg, 1971. p. 277-282.

KLINGBERG, G. Children's Fiction in the Hands of the Translators. Lund: CWK Gleerup, 1986.

NEWMARK, P. Approaches to Translation. New York, et al.: Prentice Hall, 1988.

NÖSTLINGER, C. Conrad. Illustr. Frantz Wittkamp, Übers. Anthea Bell. London: Andersen Press, 1976.

NÖSTLINGER, C. Konrad oder Das Kind aus der Konservenbüchse. Hamburg: Oetinger, 1975.

NÖSTLINGER, C. Konrad. Illustr. Carol Nicklaus. Übers. Anthea Bell. New York, London: Franklin Watts, 1977.

OITTINEN, R. Translating for Children. New York, London: Garland, 2000. 
O'SULLIVAN, E. "Kinderliterarische Übersetzen”. Fundevogel, n. 93/94, Dezember/Januar 1991/92, p. 4-9, 1992.

SHAVIT, Z. "Translation of Children's Literature". In: . Poetics of Children's Literature. Athens and London: The University of Georgia Press, 1986. p. 111-130.

THE CHILDREN'S Book Bag. Watertown: Foundation for Children's Books, Winter, 1990.

TOMLINSON, C. M. Children's Books from Other Countries. Lanham, MD, London: Scarecrow Press, 1998. 


\title{
ANEXO
}

ARTIGO ORIGINALMENTE PUBLICADO EM:

Meta: journal des traducteurs / Meta: Translators' Journal, Montréal, vol. 48, n. 1-2, 2003, p. 322-327.

Les Presses de l'Université de Montréal

ISSN: 0026-0452 (imprimé); 1492-1421 (numérique).

http://id.erudit.org/iderudit/006978ar

\section{EXPLORING CULTURAL DIFFERENCE THROUGH TRANSLATING CHILDREN'S LITERATURE}

\author{
Eva-Maria Metcalf \\ University of Mississippi, Oxford, United States
}

Résumé: L'article, de nature descriptive, traite d'un projet de traduction fait en commun avec des étudiants américains. Le projet avait pour but d'explorer l'enchâssement culturel de la langue et la nature hermeneutique de la traduction. En refléchissant aux problèmes de la traduction liés à la litterature enfantine et en imitant la situation d'un traducteur professionnel, les participants ont mieux compris le fonctionnement de la langue et les complexités associées à la traduction.

\begin{abstract}
This article is descriptive in nature, presenting a studentfaculty project in which participants translated a short children's story from German into English in order to explore the cultural embeddedness of language and the hermeneutic nature of translation. By reflecting on issues surrounding the translation of children's literature and by imitating the situation of a professional translator, project participants gained insight into the workings of language and the complexities associated with translation.

Mots-clés / Keywords: Cultural differences, German to English translation, Short story, Student-faculty project.
\end{abstract}




\section{The Project}

A few years ago, I had received funds connected with innovative teaching techniques to lead an independent-study student-faculty research project for third-year (intermediate-level) undergraduate students of German at an American university. The project consisted a group of four American students and myself, who met once a week to translate a simple children's story from German into English, the native language of the students. The idea was to produce a professional quality, publishable translation of a hitherto untranslated text closely mimicking the work of a professional translator.

Needless to say, our kind of translation was far removed from the run-of-the-mill translation practiced in the foreign-language classroom. We did not focus on language mechanics, i.e., we did not translate sentences in order to understand their meaning or to recognize or practice particular grammatical constructions. Understanding the form and content of the German children's story was an easy task indeed because of the lexical and grammatical simplicity of the chosen texts. Understanding the text was only the precondition for the ensuing work on how best to capture the meaning and flavor of the text and to establish the cultural context in which it had been situated originally and to replicate these in some way in the target language. The learning experience was aimed at a deeper understanding of the ways in which language conceptualizes the world and the difficulties we encounter in reconceptualizing it by transposing it into a different language and culture.

Because of the limited language abilities of the students who were to assume the role of professional translators with a certain level of comfort, the texts to be translated had to be very simple linguistically. Children's literature became a natural choice because of its relative linguistic simplicity. Its limited vocabulary, relatively simple syntax, its liberal use of illustrations, and the fact that the content often stays close to everyday life experiences of children made it more accessible to the learner than fiction or nonfiction written for adults. But there were more benefits in choosing 
children's literature. Its engaging plot, its tendency to render abstract or analytical thought in concrete images, its tendency to spell out concretely instead of inferring notions helps a reader unaccustomed to the culture. Moreover, children's literature's mission to socialize young readers into the thought patterns, codes, norms, values, and habits of a specific culture made it well-suited for a cross-cultural project of our kind. Our assumed role as translators forced us to detect and expose the cultural constraints imposed on children's literature in both cultures and, in the end, to heighten our awareness of the fact that we were likely to impose a second cultural filter on the story we were going to translate.

The cognitive and experiential horizons of the real and - as a consequence - the implied reader in children's literature is smaller overall than that of an adult reader, especially that of an educated adult reader. In this regard a student who is in the process of learning a foreign language and a newcomer in its culture has a great deal in common with a child reader. But the match is not perfect by any means; there exists an asymmetry between the student's mostly adult mindset and experiences and the implied reader's assumed lack thereof. In addition, the foreign student lacks the intimate knowledge of the physical, social, and moral worlds presented by and in the foreign language. This asymmetry can be overcome through the process of analyzing, interpreting, and re-encoding the story's content, images, and ideas. Children's literature itself has changed as well, making reading contemporary children's stories a more attractive proposition for students. More children's books than ever before address a dual audience of children and adults, which on the other hand comes with a dual challenge for the translator, who now has to address both audiences in the target language.

Students who do not have the bi-cultural vision required of a good translator may be blind to some of the challenges the foreign text presents. However, the deliberate effort that comes with the act of translation, namely to understand the story within its own context in order to render it in a comparable fashion in a new 
context in the target language counteracts this blindness to an extent. My role as project leader and informant about value systems and social realities in Germany at the time the story was written restored the bi-cultural vision to some extent. By being forced to compare and make decisions and resolve the existing disparities, the participating students became critical readers. Along with an understanding of the cultural differences they could glean from the text came a growing awareness of their own personal and cultural assumptions.

Beyond my desire to sensitize American students (who often have little to no experience of foreign cultures) to the role of language in the sense-making process, the project was also designed to make the learning experience more immediately cultural difference through translating children's literature meaningful and engaging. The task of translating an "authentic" text for possible publication gave students an incentive to excel, and the hands-on process of translation provided an avenue for experiential learning.

\section{The Process}

We began the project with some preparatory deliberations, such as trying to define the place of children and children's literature within the context of society and asking ourselves what would be needed for a professional quality translation of a short children's story. We discussed value-laden questions such as: What is childhood? What is a good children's book? What is a good translation? What is the function of the translator? What is the intended and implied audience of our translation? What might affect the translator's, editor's, and publisher's choices? Then followed a period of mostly serendipitous reading of and about German and American children's literature and theories of translation (based on resources in the college and local libraries, such as Eugene Nida, Peter Newmark, Zohar Shavit, Göte Klingberg) that helped us establish a working hypothesis of translation. 
The mission of the project, i.e., furthering cross-cultural understanding, was deflected into our approach to translation. We were inspired by Mildred L. Batchelder's statement from 1972 reprinted in a local children's literature publication The Children's Book Bag, "Children of one country who come to know the books and stories of many countries have made a beginning toward international understanding." (The Children's Book Bag, Winter, 1990 , p. 1) But once confronting actual translations and translating, we soon realized that this statement might make a good battle cry for advocates, such as Mildred Batchelder or Jella Lepman, but that it had to be taken with a grain of salt. This statement does not consider the effects of the inevitable screening process a children's text undergoes in the hands of translators, editors, publishers, mediators and the reader which could offset or even prevent any cross-cultural influence from happening in the first place.

We became aware of the effects that an imposition of several screening processes could have on a text by examining excerpts from the British and American editions of Christine Nöstlinger's novel Konrad oder das Kind aus der Konservenbüchse (1975), both based on Anthea Bell's translation. The differences were striking. The first chapters of the Batchelder award-winning American edition were severely shortened (the first chapter was cut by a third) and generally streamlined to stress the action-based sequences in the story. Nöstlinger's anti-authoritarian and feminist message was toned down somewhat in the British and toned down considerably in the American version of the novel. The German illustrations that had been kept in the British translation had been replaced by domesticated American illustrations, placing the Vienna children in an all-American setting.

The theoretical background and the illustrative examples prepared us to approach our own translation with greater circumspection and with determination to work against the tendency to Americanize that seemed prevalent in American translations from the 1970s and 1980s. The fact that only $1.2 \%$ of all books produced in the United States were translations in 1995 (Tomlinson, 1998, p. 14) 
compared to roughly $80 \%$ in Finland during the same decade, as Riitta Oittinen points out (Oittinen, 2000, p. XIII), produces a readership in the United States that has little knowledge of and a low tolerance for foreignness. Many of the books that are translated in the United States have gone through a rigid selection process based on projections of their potential adoption by consumers and their financial success. This results in a "natural" selection of books that are adaptable to the target culture.

A five-page short story by Susanne Kilian, "Jürgen Körner, 8 Jahre, 2. Schuljahr" published in 1971 in the anthology of children's literature, Geh, spiel mit dem Riesen served as the main text for the project. This short and simple story proved to be rewarding from a social and cultural point of view. Written in minimalist, rather terse prose, the first-person narrative gives readers glimpses into the life of a neglected 8-year old boy. It tells us about his everyday life at home and in school caught within a web of abuse received and committed. Most sentences are main clauses, the longest syntactic feature is a simple combination of main and dependent clause and the vocabulary consists of the vocabulary of an eight-year-old not too articulate child. (In second language acquisition terminology the language used is at the intermediate-low to intermediate-mid level)

Once we had read and discussed the story to gain an impression and compare our responses to it, we discussed the story's underlying concept of childhood and its ideological stance and message. Perceptions of the author's concept of childhood varied as did perceptions of the translator's attitudes toward implied readers. Which of our personal preferences should prevail? We were equally divided on what to do with the leftist ideology in a text that has little resonance in target culture. Should we retain it? Is adaptation a necessity, a self-preservation, or self-censorship?

Full of unresolved questions we approached the task of sentenceby-sentence translation. We all translated an assigned passage from the text individually and during meetings we compared and discussed our results. During the discussion sessions students 
had ample opportunity to vent their ideas again. Stylistic as well as semantic and ideological issues were soon at the heart of at times heated debates about target language renditions. Despite the simplicity of language and the limitations of content, the story contained an amazing amount of culturally specific information. Finding the right register, tone, and rhythm was not as simple as it had seemed originally. Perhaps the greatest challenge was posed by culturally specific words and concepts. How do we translate personal and geographic names, food items, games, and traditions that do not exist in the target culture? How do we render words like "Pausenbrot" which is not the same as a lunch pail, since school lunch does not exist in Germany? "Schulranzen" was equally untranslatable with backpack. It does get the message across that German children wear their school bags on the back, but it does not relay the message of expected neatness and home supervision of homework upon which the story hinges. We kept backpack and tried to stress the neatness with which papers and pencils are stored in other ways. How do we explain the importance of the preChristmas tradition of the German "Adventskranz" to American readers, since the full understanding of the story hinges on it? A footnote explanation seemed clumsy, but I believe, we opted for it. For the most part, our conflicting views were resolved in a compromise position on translation and resulted in a more-or-less consistent translation. However, it brought to the fore the culturally determined and subjective quality of translation, which was the sought-after learning experience.

Most of our discussions led us back to the fundamental question translators have posed themselves for centuries. How does one translate a set of different norms cultural difference through translating children's literature and values, an unfamiliar body of references and connotations, and culturally specific expressions and concepts and make it seem comfortable for the reader without losing its cultural significance? These discussions that strike at the heart of translation also took us far afield into the history, politics, and everyday life of both cultural areas. 


\section{The Outcome}

In the end, we did not publish our translation, although it had been one of the aims of our project. It was after all not the product (although an important impetus for the project) but the process that counted, and it was the process that provided the learning experience. Putting the translation on the web and challenging others to improve it, would have been a great idea, and one I would like to pursue in the future. However, the project led to research papers, which the students presented at a national conference for undergraduate research the following semester.

The focus of these papers was an attempt to find an answer to the questions we had debated as we decided on our translation. To a large extent, students opted against adaptation to the target culture and making the text more reader-friendly and for keeping intact much of the otherness of the foreign culture in their translation. Their efforts to shape their translations so that American children could gain a broader vision by experiencing difference and in that manner gain a modicum of cross cultural knowledge was clearly a political decision on their part at a time when multiculturalism and emerging globalization became household words. It underlined the fact that translation will always be subject to political, moral, social, economic, cultural, religious, ideological, psychological and other pressures that have to be acknowledged. Because of children's literature's perceived mission to educate, the young students felt inclined to slip into the role of educator as translator, which seems to be a role not unfamiliar to many translators, editors and publishers of chjldren's literature. This attitude has - at least in the United States - produced exceedingly acculturated translations of children's stories, which are much less reprehensible and blander than the original texts.

Some results of the project were expected, others seemed like an added bonus. It goes without saying that the project improved the linguistic ability of the students. Working closely and creatively with language improved their command of grammar and vocabulary 
and their sensitivity to register and style. Making the role of the translator visible also enhanced their love of language and respect for the translator's craft. By the end of the project students' appreciation for the complexity of translation had grown manifold. The teamwork of a joint translation harnessed competitiveness into cooperation. Students became experts by embarking on a professional translation from simple German into English and could and did take pride in their work. Finally, is there a better way of learning than learning from experience?

\section{Note}

1. O artigo, originalmente intitulado "Exploring Cultural Difference Through Translating Children's Literature", foi publicado por Meta: journal des traducteurs / Meta: Translators' Journal, Montréal, vol. 48, n. 1-2, 2003, p. 322-327.

\section{References}

Kilian, S. (1971): "Jürgen Körner, 8 Jahre, 2. Schuljahr," in Geh, spiel mit dem Riesen. Weinheim und Basel: Beltz \& Gelberg pp. 277-282.

Klingberg, G. (1986): Children's Fiction in the Hands of the Translators. Lund: CWK Gleerup.

Newmark, P. (1988): Approaches to Translation. New York, et al.: Prentice Hall. 
Nöstlinger, C (1976): Conrad. Illustr. Frantz Wittkamp, Übers. Anthea Bell. London: Andersen Press.

Nöstlinger, C. (1975): Konrad oder Das Kind aus der Konservenbüchse. Hamburg: Oetinger.

Nöstlinger, C. (1977): Konrad Illustr. Carol Nicklaus. Übers. Anthea Bell. New York, London: Franklin Watts.

Oittinen, R. (2000): Translating for Children. New York, London: Garland.

O’Sullivan, E.: “Kinderliterarische Übersetzen” in Fundevogel 93/94, Dezember/ Januar 1991/92, pp. 4-9.

Shavit, Z. (1986): “Translation of Children's Literature” in Poetics of Children's Literature. Athens and London: The University of Georgia Press, pp. 111-130.

The Children's Book Bag (Winter, 1990). Watertown: Foundation for Children's Books.

Tomlinson, C. M. (1998) Children's Books from Other Countries. Lanham, MD, London: Scarecrow Press.

Recebido em: 18/07/2015

Aceito em: 19/10/2015 